Гандзюк М.О.,Гандзюк Д.М.

Луиький національний технічний університет

\title{
ДО ПИТАННЯ ДОСЛІДЖЕННЯ РУХУ МОДУЛЬНОГО ТРИЛАНКОВОГО ПРИЧІПНОГО АВТОПОӤЗДА У СКЛАДІ «АВТОМОБІЛЬ-ТЯГАЧ - ДВОВІСНИЙ ПІДКАТНИЙ ВІЗОК - ТРИВІСНИЙ НАПІВПРИЧІП» У ГАЛЬМІВНОМУ РЕЖИМІ
}

\footnotetext{
У роботі визначено основні кінематичні та геометричні співвідношення та розроблено рівняння для знаходження кутів відведення коліс осей ланок при русі модульного триланкового причіпного автопоїзда у складі «автомобіль-тягач - двовісний підкатний візок - тривісний напівпричіп» у гальмівному режимі.

Це дозволить у теоретичних дослідженнях визначати вплив компонувальної схеми та режимів руху вказаного автопоїзда на його стійкість у гальмівному режимі з урахуванням кутів встановлення осей.

Ключові слова: автопоїзд; модульний триланковий причіпний автопоїзд; компонувальна схема; причіпна ланка; причіп; напівпричіп; підкатний візок; математична модель; експлуатаційні властивості; стійкість; гальмівний режим.
}

Постановка проблеми. Вирішення проблем, пов'язаних 3 безпекою руху триланкових автопоїздів не розв'язується тільки застосуванням електронних систем: автоматичного усунення блокування колеса (АБС), системи розподілу гальмівних зусиль (EBD), системи стабілізації руху (ESP), та інших. Такі системи дозволяють значно покращити гальмівні властивості автотранспортних засобів, підвищити стійкість триланкового автопоїзда у гальмівному режимі.

Погіршення стійкості автопоїзда може призвести до фатальних наслідків. Тому є необхідність дослідження впливу компонувальних та експлуатаційних факторів на стійкість триланкового автопоїзда у гальмівному режимі.

Вирішення цих проблем неможливе без розробки математичної моделі руху модульного триланкового причіпного автопоїзда, у якій були б враховані основні кінематичні та геометричні співвідношення, кути встановлення осей, нормальні реакції опорної поверхні та бічні сили на колесах осей ланок з урахуванням їх перерозподілу по осях та бортах при гальмуванні автопоїзда у криволінійному та прямолінійному русі а також кути відведення коліс автомобіля-тягача, підкатного візка та напівпричепа.

Аналіз останніх досліджень і публікацій. Аналіз публікацій показує, що робіт, присвячених дослідженню експлуатаційних властивостей багатоланкових автопоїздів (насамперед, триланкових) порівняно не багато. Так, у роботах [6], [7], [8], [9] розглянуто рух триланкових автопоїздів різних компонувальних схем у різних режимах руху. Дослідженню маневреності та стійкості руху автопоїздів компонувальної схеми «автомобіль-тягач - двовісний підкатний візок - тривісний напівпричіп» присвячені роботи [1], [8].

На сьогодні існує багато конструкцій багатоланкових автопоїздів. На наш погляд компонувальна схема модульного автопоїзда 3 тривісним напівпричепом, двовісним підкатним візком і тривісним напівпричепом $є$ найбільш універсальною.

Крім того, завдяки введенню у математичну модель сил взаємодії кожного колеса 3 дорогою, можливо моделювання різних режимів руху автопоїзда (тягового, вільного та гальмівного), а також можливо враховувати вплив перерозподілу мас по осях та між бортами ланок автопоїзда.

Дослідженню експлуатаційних властивостей автопоїздів присвячені роботи Д.О. Антонова, С.С. Атаєва, В.Г. Вербицького, Д.Р. Елліса, Я.Х. Закіна, Е.М. Ібрагімова, А.П. Колпакова, М.I. Кришеня, Л.Г. Лобаса, М. Мічке, С.Я. Марголіса, В.П. Сахно, Я.С. Фаробіна а також інших вітчизняних та закордонних вчених. Аналіз публікацій показує, що достатньо добре вивчені закономірності руху дволанкових автопоїздів. Робіт, присвячених дослідженню багатоланкових автопоїздів (насамперед, триланкових) порівняно не багато. Ця тематика почала досліджуватися в останні роки.

При наявності у автопоїзда більше трьох ланок суттєво ускладнюється дослідження руху такого багатоланкового АТЗ з причини необхідності врахування впливу значної кількості факторів на характер руху усіх ланок. Взаємодія сусідніх ланок при русі автопоїзда розповсюджується на весь транспортний засіб і призводить до певних відхилень складових автопоїзда від заданого ведучою ланкою (тягачем) напрямку руху. Враховуючи те, що автопоїзд як АТЗ є засобом підвищеної небезпеки, при вирішенні проблем щодо можливості експлуатації багатоланкових автопоїздів у числі 
перших слід робити кроки у напрямку теоретичних досліджень їх руху, результати яких будуть підгрунтям для відповіді на багато питань технічного, організаційного, юридичного характеру.

На підставі наведеного компонувальну схему автопоїзда 3 тривісним автомобілем-тягачем, двовісним підкатним візком і тривісним напівпричепом як універсальну та перспективну (розроблено фірмами «Scania» та «Krone») обрано для дослідження його стійкості у гальмівному режимі 3 урахуванням кутів встановлення осей, що, насамперед, впливає на безпеку руху.

Плоска математична модель руху модульного триланкового причіпного автопоїзда у складі «автомобіль-тягач - двовісний підкатний візок - тривісний напівпричіп» була розроблена у роботі [1]. Проте у цій математичній моделі осі ланок автопоїзда неповоротні. Також у ній не враховано кути відведення коліс осей ланок автопоїзда.

При розробці математичних моделей руху модульних триланкових причіпних автопоїздів у гальмівному режимі з урахуванням кутів встановлення його осей необхідно визначити основні кінематичні та геометричні співвідношення та отримати рівняння для визначення нормальних реакцій опорної поверхні та бічних сил на колесах осей ланок з урахуванням їх перерозподілу по осях та бортах при гальмуванні автопоїзда у криволінійному та прямолінійному русі а також кутів відведення коліс автомобіля-тягача, підкатного візка та напівпричепа.

Мета роботи. Метою дослідження є визначення основних кінематичних та геометричних співвідношень та розробка рівнянь для знаходження кутів відведення коліс осей ланок при русі модульного триланкового причіпного автопоїзда у складі «автомобіль-тягач - двовісний підкатний візок - тривісний напівпричіп» (рисунки 1, 2, 3, 4), які б дозволили у теоретичних дослідженнях визначати вплив компонувальної схеми та режимів руху на його стійкість у гальмівному режимі 3 урахуванням кутів встановлення осей.

Викладення основного матеріалу. Значний вплив на безпеку руху автопоїздів має їх стійкість у різних режимах руху. В процесі дослідження розглянемо триланковий сідельний автопоїзд у складі тривісного автомобіля-тягача, двовісного підкатного візка та тривісного напівпричепа, як найбільш вживаний на сьогодні при перевезенні вантажів.

Під технічною стійкістю при гальмуванні розумітимемо забезпечення гальмування автопоїзда до повної його зупинки без виходу за межі безпечного коридору. Відповідно до прийнятої розрахункової схеми, в якості оціночних критеріїв можна використовувати кути повороту в горизонтальній площині кінематичних ланок автопоїзда $\vartheta$, кути складання ланок автопоїзда $\varphi$ та поперечне переміщення центрів мас ланок.

Для проведення математичного опису плоскопаралельного руху сідельного автопоїзда 3 можливістю урахування змін, які відбуваються в ходовій частині та гальмівній системі в процесі експлуатації, введемо ряд спрощень та припущень. Вважатимемо що:

- автомобіль-тягач, підкатний візок та напівпричіп рухаються рівною горизонтальною поверхнею;

- основною траєкторією руху автопоїзда є траєкторія центра мас автомобіля-тягача;

- в опорно-зчіпних пристроях відсутні тертя, зазори та пружні елементи;

- у шарнірах рульового приводу люфти відсутні;

- гіроскопічні моменти та неврівноважені моменти обертових частин не приймаються до уваги;

- рами автомобіля тягача, підкатного візка та напівпричепа є твердими тілами 3 поздовжньою віссю симетрії, їх деформації на кручення та згин відсутні;

- координати центрів непідресорених і підресорених мас визначаються у положенні статичної рівноваги ланок автопоїзда;

- пружні елементи підвіски ланок автопоїзда вважатимемо безмасовими, вони характеризуються лише податливістю, а їх маси віднесемо до підресорених та непідресорених мас ланок;

- демпфуючі властивості підвіски та шин ланок автопоїзда не враховуються;

- положення вантажу на автомобілі та напівпричепі вважатимемо таким, що забезпечує розташування центрів мас ланок у вертикальній площині їх симетрії;

- взаємодію шин 3 опорною поверхнею у бічному напрямку описуємо із використанням нелінійної теорії відведення Д. А. Антонова.

Відповідно до прийнятих умов та припущень зобразимо розрахункову схему модульного триланкового причіпного автопоїзда у складі «автомобіль-тягач - двовісний підкатний візок тривісний напівпричіп» (рисунок 1).

Введемо наступні позначення:

$O x y z$ - інерційна система координат; 
$m_{1}, C_{1}, I_{1}$ - маса, центр мас і центральний момент інерції ведучої ланки відносно вертикальної осі, що проходить через центр мас (точка $C_{1}$ );

$m_{2}, C_{2}, I_{2}$ - маса, центр мас і центральний момент інерції веденої ланки відносно вертикальної осі, що проходить через центр мас (точка $C_{2}$ );

$m_{3}, C_{3}, I_{3}$ - маса, центр мас і центральний момент інерції веденої ланки відносно вертикальної осі, що проходить через центр мас (точка $C_{3}$ );

$x_{1}, y_{1}$ - абсциса і ордината точки $C_{1}$ в системі координат $O x y z$;

$x_{2}, y_{2}$ - абсциса і ордината точки $C_{2}$ в системі координат $O x y z$;

$x_{3}, y_{3}$ - абсциса і ордината точки $C_{3}$ в системі координат $O x y z$;

$\vartheta_{1}, \vartheta_{2}, \vartheta_{3}$ - курсові кути ланок автопоїзда;

$\omega_{1}, \omega_{2}, \omega_{3}$, - кутові швидкості ланок автопоїзда;

$\theta_{1}$ - кут повороту керованих коліс;

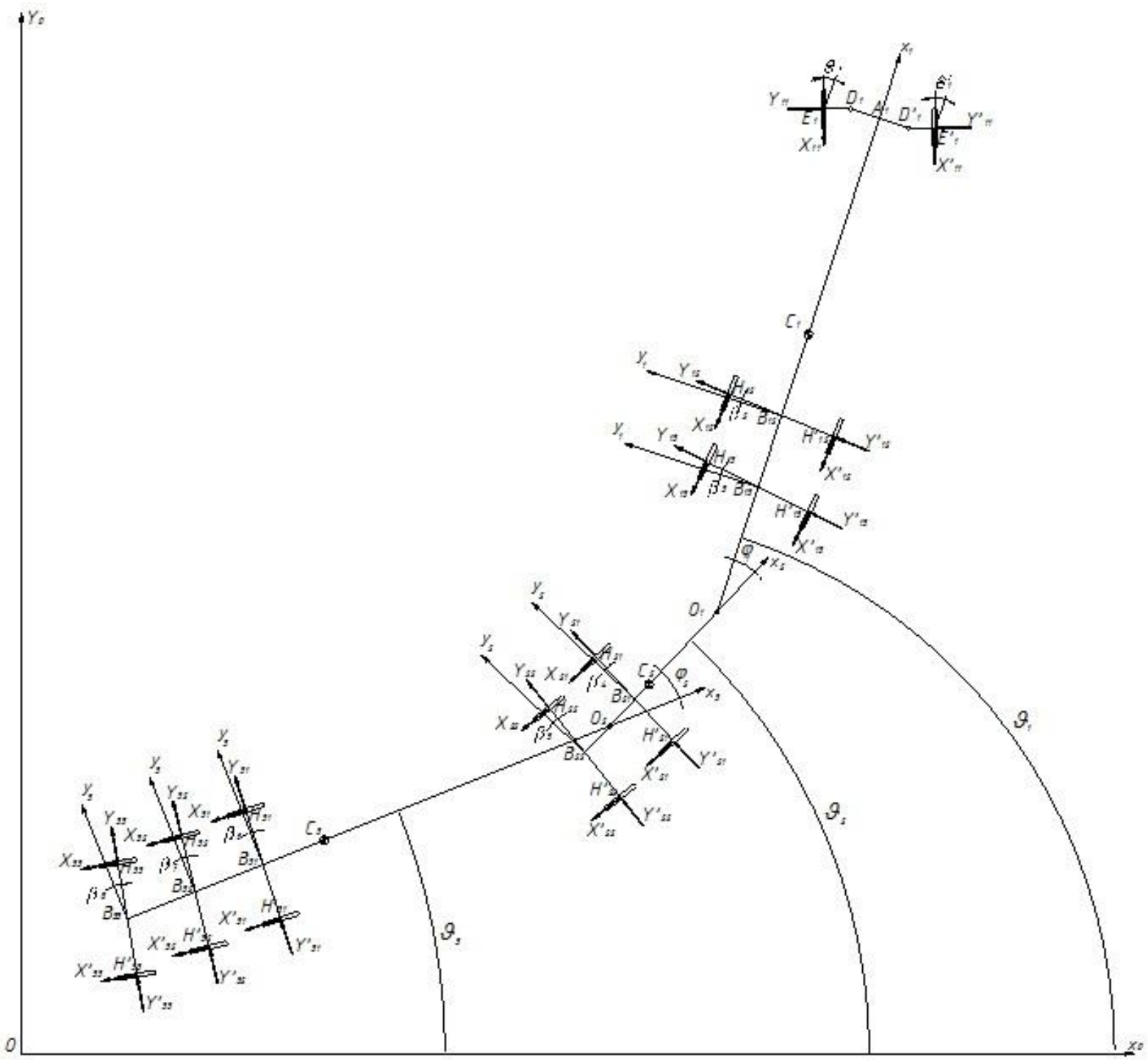

Рисунок 1 - Розрахункова схема триланкового причіпного автопоїзда у плоскопаралельному русі

$v_{1}=\dot{x}_{1} \cos \vartheta_{1}+\dot{y}_{1} \sin \vartheta_{1}, u_{1}=-\dot{x}_{1} \sin \vartheta_{1}+\dot{y}_{1} \cos \vartheta_{1}-$ проекції швидкості точки $C_{1}$ на поздовжню і поперечну осі ведучої ланки;

$v_{2}, u_{2}$ - поздовжня і поперечна проекції вектора швидкості центра мас $C_{2}$ підкатного візка;

$v_{3}, u_{3}$ - поздовжня і поперечна проекції вектора швидкості центра мас $C_{3}$ напівпричепа; 
$\varphi_{1}, \varphi_{2}$ - кути складання ланок автопоїзда;

$\beta_{i}$ - кут перекосу $i$-ої осі автопоїзда;

$a_{1}$ - відстань від передньої осі автомобіля -тягача до центра мас автомобіля -тягача;

$b_{12}$ - відстань від центра мас автомобіля-тягача до середньої осі автомобіля -тягача;

$b_{13}$ - відстань від центра мас автомобіля-тягача до задньої осі автомобіля -тягача;

$l_{S_{12}}$ - відстань від середньої осі автомобіля-тягача до точки зчіпки з підкатним візком;

$l_{S_{13}}$ - відстань від задньої осі автомобіля-тягача до точки зчіпки з підкатним візком;

$c_{1}$ - відстань від центра мас автомобіля-тягача до точки зчіпки з підкатним візком;

$a_{2}$ - відстань від точки зчіпки автомобіля -тягача 3 підкатним візком до центра мас підкатного візка;

$b_{21}$ - відстань від центра мас підкатного візка до першої осі підкатного візка;

$b_{22}$ - відстань від центра мас підкатного візка до другої осі підкатного візка;

$l_{S_{21}}$ - відстань від першої осі підкатного візка до точки зчіпки з напівпричепом;

$l_{S_{22}}$ - відстань від другої осі підкатного візка до точки зчіпки з напівпричепом;

$c_{2}$ - відстань від центра мас підкатного візка до точки зчіпки з напівпричепом;

$a_{3}$ - відстань від точки зчіпки підкатного візка з напівпричепом до центра мас напівпричепа;

$b_{31}$ - відстань від центра мас напівпричепа до першої осі напівпричепа;

$b_{32}$ - відстань від центра мас напівпричепа до другої осі напівпричепа;

$b_{33}$ - відстань від центра мас напівпричепа до третьої осі напівпричепа.

Індекси: 1, 2, 3 - стосуються відповідно тягача, підкатного візка та напівпричепа.

Параметри з позначкою «штрих» відносяться до коліс правого борту автопоїзда, без такої - до коліс лівого борту.

Наведемо основні геометричні параметри автопоїзда:

$$
\begin{array}{lll}
a_{1}=C_{1} A_{1}, & a_{2}=C_{2} O_{1}, & a_{3}=C_{3} O_{2}, \\
b_{12}=C_{1} B_{12}, & b_{21}=C_{2} B_{21}, & b_{31}=C_{3} B_{31}, \\
b_{13}=C_{1} B_{13}, & b_{22}=C_{2} B_{22}, & b_{32}=C_{3} B_{32}, \\
c_{1}=C_{1} O_{1}, & c_{2}=C_{2} O_{2}, & b_{33}=C_{3} B_{33}, \\
p_{1}=D_{1} E_{1}, & l_{S_{21}}=O_{2} B_{21}, & n_{31}=B_{31} H_{31}, \\
p_{1}^{\prime}=D_{1}^{\prime} E_{1}^{\prime}, & l_{S_{22}}=O_{2} B_{22}, & n_{31}^{\prime}=B_{31} H_{31}^{\prime}, \\
l_{S_{12}}=O_{1} B_{12}, & n_{21}=B_{21} H_{21}, & n_{32}=B_{32} H_{32}, \\
l_{S_{13}}=O_{1} B_{13}, & n_{21}^{\prime}=B_{21} H_{21}^{\prime}, & n_{32}^{\prime}=B_{32} H_{32}^{\prime}, \\
n_{1}=A_{1} D_{1}, & n_{22}=B_{22} H_{22}, & n_{33}=B_{33} H_{33}, \\
n_{1}^{\prime}=A_{1} D_{1}^{\prime}, & n_{22}^{\prime}=B_{22} H_{22}^{\prime}, & n_{33}^{\prime}=B_{33} H_{33}^{\prime} . \\
n_{12}=B_{12} H_{12}, & & \\
n_{12}^{\prime}=B_{12} H_{12}^{\prime}, & & \\
n_{13}=B_{13} H_{13}, & & \\
n_{13}^{\prime}=B_{13} H_{13}^{\prime}, & &
\end{array}
$$

Визначимо основні кінематичні та геометричні співвідношення, зокрема проекції швидкостей ланок автопоїзда на поздовжню та поперечну осі та координати характерних точок.

По аналогії 3 [4] швидкість центра мас автомобіля-тягача, що здійснює плоско-паралельний рух по рухомому базису $i_{1}, j_{1}$ (орти осей $X_{0}, Y_{0}$ ) запишемо у вигляді

$$
v_{C_{1}}=i_{1} v_{1}+j_{1} u_{1} .
$$

Поздовжню і бічну проекції швидкості центра мас автомобіля-тягача та його абсолютну кутову швидкість знайдемо з виразів 


$$
\begin{gathered}
v_{1}=\dot{x}_{1} \cos \vartheta_{1}+\dot{y}_{1} \sin \vartheta_{1} ; \\
u_{1}=-\dot{x}_{1} \sin \vartheta_{1}+\dot{y}_{1} \cos \vartheta_{1} ; \\
\omega_{1}=\dot{\vartheta}_{1} .
\end{gathered}
$$

Швидкість центра мас підкатного візка, поздовжню і бічну проекції швидкості центра мас підкатного візка та його абсолютну кутову швидкість та кутове прискорення знайдемо з виразів

$$
\begin{gathered}
v_{C_{2}}=i_{2} v_{2}+j_{2} u_{2} ; \\
v_{2}=\dot{x}_{2} \cos \vartheta_{2}+\dot{y}_{2} \sin \vartheta_{2} ; \\
u_{2}=-\dot{x}_{2} \sin \vartheta_{2}+\dot{y}_{2} \cos \vartheta_{2} ; \\
\omega_{2}=\dot{\vartheta}_{2}=\omega_{1}-\dot{\varphi}_{1} ; \\
\dot{\omega}_{2}=\dot{\omega}_{1}-\ddot{\varphi}_{1} .
\end{gathered}
$$

Швидкість центра мас напівпричепа, поздовжню і бічну проекції швидкості центра мас напівпричепа та його абсолютну кутову швидкість та кутове прискорення знайдемо з виразів

$$
\begin{gathered}
v_{C_{3}}=i_{2} v_{3}+j_{2} u_{3} ; \\
v_{3}=\dot{x}_{3} \cos \vartheta_{3}+\dot{y}_{3} \sin \vartheta_{3} ; \\
u_{3}=-\dot{x}_{3} \sin \vartheta_{3}+\dot{y}_{3} \cos \vartheta_{3} ; \\
\omega_{3}=\dot{\vartheta}_{3}=\omega_{2}-\dot{\varphi}_{2} ; \\
\dot{\omega}_{3}=\dot{\omega}_{2}-\ddot{\varphi}_{2} .
\end{gathered}
$$

Швидкості точок зчіпки ланок автопоїзда знайдемо з виразів:

відносно автомобіля тягача та підкатного візка

$$
\begin{gathered}
v_{O_{1}}=v_{C_{1}}+\omega_{1} \times C_{1} O_{1}=i_{1} v_{1}+j_{1}\left(u_{1}-\omega_{1} c_{1}\right)= \\
=i_{2}\left[v_{1} \cos \varphi_{1}-\left(u_{1}-\omega_{1} c_{1}\right) \sin \varphi_{1}\right]+j_{2}\left[v_{1} \sin \varphi_{1}+\left(u_{1}-\omega_{1} c_{1}\right) \cos \varphi_{1}\right] ; \\
v_{O_{1}}=v_{C_{2}}+\omega_{2} \times C_{2} O_{1}=i_{2} v_{2}+j_{2}\left(u_{2}+\omega_{2} a_{2}\right) ;
\end{gathered}
$$

тоді поздовжню і бічну проекції швидкості центра мас підкатного візка знайдемо з виразів

$$
\begin{gathered}
v_{2}=v_{1} \cos \varphi_{1}-\left(u_{1}-\omega_{1} c_{1}\right) \sin \varphi_{1} \\
u_{2}=v_{1} \sin \varphi_{1}+\left(u_{1}-\omega_{1} c_{1}\right) \cos \varphi_{1}-\omega_{2} a_{2} .
\end{gathered}
$$

відносно підкатного візка та напівпричепа

$$
\begin{gathered}
v_{O_{2}}=v_{C_{2}}+\omega_{2} \times C_{2} O_{1}=i_{2} v_{2}+j_{2}\left(u_{2}-\omega_{2} c_{2}\right)= \\
=i_{3}\left[v_{2} \cos \varphi_{2}-\left(u_{2}-\omega_{2} c_{2}\right) \sin \varphi_{2}\right]+j_{3}\left[v_{2} \sin \varphi_{2}+\left(u_{2}-\omega_{2} c_{2}\right) \cos \varphi_{2}\right] ; \\
v_{O_{2}}=v_{C_{3}}+\omega_{3} \times C_{3} O_{2}=i_{3} v_{3}+j_{3}\left(u_{3}+\omega_{3} a_{3}\right) ;
\end{gathered}
$$

тоді поздовжню і бічну проекції швидкості центра мас напівпричепа знайдемо з виразів

$$
\begin{gathered}
v_{3}=v_{2} \cos \varphi_{2}-\left(u_{2}-\omega_{2} c_{2}\right) \sin \varphi_{2} \\
u_{3}=v_{2} \sin \varphi_{2}+\left(u_{2}-\omega_{2} c_{2}\right) \cos \varphi_{2}-\omega_{3} a_{3} .
\end{gathered}
$$

Величини $v, u, \omega, \varphi$ знаходяться з диференціальних рівнянь руху автопоїзда.

Координати центра мас і курсовий кут автомобіля тягача визначаються за допомогою системи кінематичних рівнянь: 


$$
\begin{gathered}
\dot{x}_{1}=v_{1} \cos \vartheta_{1}-u_{1} \sin \vartheta_{1} ; \\
\dot{y}_{1}=v_{1} \sin \vartheta_{1}+u_{1} \cos \vartheta_{1} ; \\
\dot{\vartheta}_{1}=\omega_{1} .
\end{gathered}
$$

Використавши рівняння (7) можна визначити абсциси та ординати будь-яких точок автопоїзда. Знайдемо координати характерних точок (рисунок 1).

Для автомобіля тягача:

$$
\begin{aligned}
& x_{C_{1}}=x_{1} ; \quad x_{A_{1}}=x_{1}+a_{1} \cos \vartheta_{1} ; \quad x_{B_{12}}=x_{1}-b_{12} \cos \vartheta_{1} ; \quad x_{B_{13}}=x_{1}-b_{13} \cos \vartheta_{1} ; \quad x_{O_{1}}=x_{1}-c_{1} \cos \vartheta_{1} ; \\
& y_{C_{1}}=y_{1} ; \quad y_{A_{1}}=y_{1}+a_{1} \sin \vartheta_{1} ; \quad x_{B_{12}}=y_{1}-b_{12} \sin \vartheta_{1} ; \quad x_{B_{13}}=y_{1}-b_{13} \sin \vartheta_{1} ; \quad y_{O_{1}}=y_{1}-c_{1} \sin \vartheta_{1} \text {. }
\end{aligned}
$$

Для підкатного візка:

$$
\begin{aligned}
& x_{C_{2}}=x_{2} ; \quad x_{B_{21}}=x_{2}-b_{21} \cos \vartheta_{2} ; \quad x_{B_{22}}=x_{2}-b_{22} \cos \vartheta_{2} ; \quad x_{O_{1}}=x_{2}+a_{2} \cos \vartheta_{2} ; \quad x_{O_{2}}=x_{2}-c_{2} \cos \vartheta_{2} ; \\
& y_{C_{2}}=y_{2} ; \quad y_{B_{21}}=y_{2}-b_{21} \sin \vartheta_{2} ; \quad y_{B_{22}}=y_{2}-b_{22} \sin \vartheta_{2} ; \quad y_{O_{1}}=y_{2}+a_{2} \sin \vartheta_{2} ; \quad y_{O_{2}}=y_{2}-c_{2} \sin \vartheta_{2} \text {. }
\end{aligned}
$$

Для напівпричепа:

$$
\begin{aligned}
& x_{C_{3}}=x_{3} ; \quad x_{B_{31}}=x_{3}-b_{31} \cos \vartheta_{3} ; \quad x_{B_{32}}=x_{3}-b_{32} \cos \vartheta_{3} ; \quad x_{B_{33}}=x_{3}-b_{33} \cos \vartheta_{3} ; \quad x_{O_{2}}=x_{3}+a_{3} \cos \vartheta_{3} ; \\
& y_{C_{3}}=y_{3} ; \quad y_{B_{31}}=y_{3}-b_{31} \sin \vartheta_{3} ; \quad y_{B_{32}}=y_{3}-b_{32} \sin \vartheta_{3} ; \quad y_{B_{33}}=y_{3}-b_{33} \sin \vartheta_{3} ; \quad y_{O_{2}}=y_{3}+a_{3} \sin \vartheta_{3} \text {. }
\end{aligned}
$$

Виведемо рівняння для знаходження кутів відведення коліс осей ланок при русі модульного триланкового причіпного автопоїзда у складі «автомобіль-тягач - двовісний підкатний візок тривісний напівпричіп» (рисунки 2, 3, 4), яка б дозволяла у теоретичних дослідженнях визначати вплив компонувальної схеми та режимів руху на його стійкість при гальмуванні. Для цього скористаємось методикою, наведеною у роботі [10]. Розглянемо колеса передньої керованої осі автомобіля-тягача. Кути обертання, центри повороту та центри плям контакту коліс 3 опорною поверхнею позначимо відповідно через $\theta_{1}, D_{1}, E_{1}$. Приймаючи до уваги прийняті умовні позначення швидкість центрів плям контакту коліс з опорною поверхнею знайдемо із рівнянь

$$
\begin{aligned}
& v_{E_{1}}=v_{C_{1}}+\dot{\theta}_{1}\left(C_{1} A_{1}+A_{1} D_{1}+D_{1} E_{1}\right)+\dot{\theta}_{1} \cdot D_{1} E_{1} ; \\
& v_{E_{1}^{\prime}}=v_{C_{1}}+\dot{\theta}_{1}^{\prime}\left(C_{1} A_{1}+A_{1} D_{1}^{\prime}+D_{1}^{\prime} E_{1}^{\prime}\right)+\dot{\theta}_{1}^{\prime} \cdot D_{1}^{\prime} E_{1}^{\prime} .
\end{aligned}
$$

Із врахуванням рівнянь $(2,3,4,5,6)$ та прийнятих позначень отримаємо:

$$
\begin{aligned}
& v_{E_{1}}=i_{1}\left[v_{1}-\omega_{1}\left(n_{1}+p \cos \theta_{1}\right)-\dot{\theta}_{1} p \cos \theta_{1}\right]+j_{1}\left[u_{1}+\omega_{1}\left(a_{1}-p \sin \theta_{1}\right)-\dot{\theta}_{1} p \sin \theta_{1}\right] \\
& v_{E_{1}^{\prime}}=i_{1}\left[v_{1}+\omega_{1}\left(n_{1}^{\prime}+p^{\prime} \cos \theta_{1}^{\prime}\right)+\dot{\theta}_{1}^{\prime} p^{\prime} \cos \theta_{1}^{\prime}\right]+j_{1}\left[u_{1}+\omega_{1}\left(a_{1}+p^{\prime} \sin \theta_{1}^{\prime}\right)+\dot{\theta}_{1}^{\prime} p^{\prime} \sin \theta_{1}^{\prime}\right] .
\end{aligned}
$$

Оскільки

$$
\begin{aligned}
& \operatorname{tg}\left(\theta_{1}-\delta_{1}\right)=\frac{\left(v_{E_{1}}\right)_{Y_{0}}}{\left(v_{E_{1}}\right)_{X_{0}}}, \\
& \operatorname{tg}\left(\theta_{1}^{\prime}-\delta_{1}^{\prime}\right)=\frac{\left(v_{E_{1}^{\prime}}\right)_{Y_{0}}}{\left(v_{E_{1}^{\prime}}\right)_{X_{0}}} ;
\end{aligned}
$$

то кути відведення коліс передньої осі автомобіля-тягача знайдемо із виразів: 


$$
\begin{aligned}
& \delta_{1}=\theta_{1}-\operatorname{arctg}\left[\frac{u_{1}+\omega_{1}\left(a_{1}-p \sin \theta_{1}\right)-\dot{\theta}_{1} p \sin \theta_{1}}{v_{1}-\omega_{1}\left(n_{1}+p \cos \theta_{1}\right)-\dot{\theta}_{1} p \cos \theta_{1}}\right] ; \\
& \delta_{1}^{\prime}=\theta_{1}^{\prime}-\operatorname{arctg}\left[\frac{u_{1}+\omega_{1}\left(a_{1}+p^{\prime} \sin \theta_{1}^{\prime}\right)+\dot{\theta}_{1}^{\prime} p^{\prime} \sin \theta_{1}^{\prime}}{v_{1}+\omega_{1}\left(n_{1}^{\prime}+p^{\prime} \cos \theta_{1}^{\prime}\right)+\dot{\theta}_{1}^{\prime} p^{\prime} \cos \theta_{1}^{\prime}}\right] .
\end{aligned}
$$

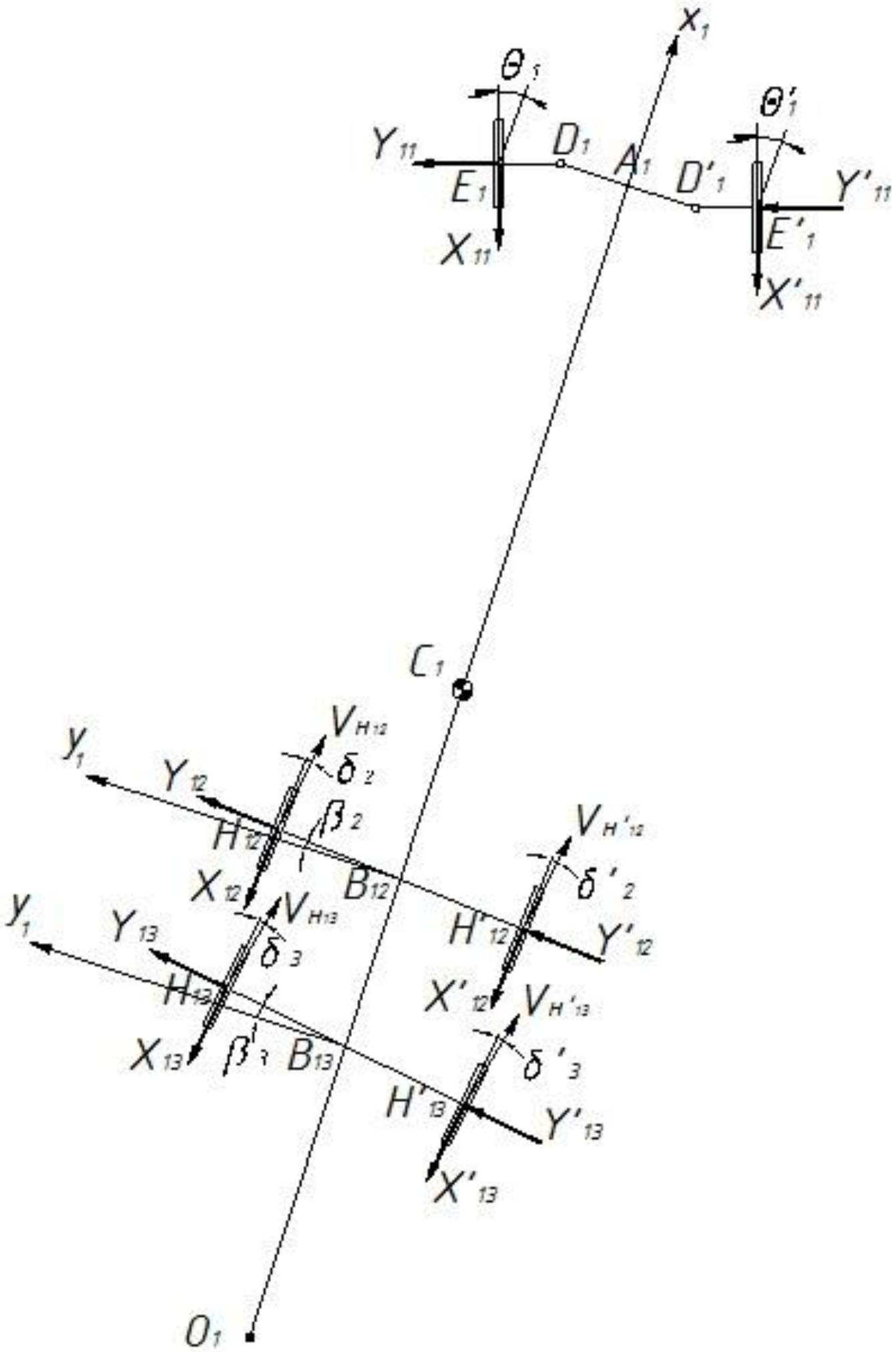

Рисунок 2 - До визначення кутів відведення коліс автомобіля-тягача 
3 урахуванням кута $\beta_{2}$ перекосу середнього моста автомобіля-тягача, швидкості центрів плям контакту коліс середньої осі автомобіля-тягача з опорною поверхнею знайдемо з виразів:

$$
\begin{aligned}
& v_{H_{12}}=v_{C_{1}}+\dot{\vartheta}_{1}\left(C_{1} B_{12}+B_{12} H_{12}\right)+\dot{\beta}_{2} \cdot B_{12} H_{12} \\
& v_{H_{12}^{\prime}}=v_{C_{1}}+\dot{\vartheta}_{1}\left(C_{1} B_{12}+B_{12} H_{12}^{\prime}\right)+\dot{\beta}_{2} \cdot B_{12} H_{12}^{\prime} .
\end{aligned}
$$

3 урахуванням кута $\beta_{3}$ перекосу заднього моста автомобіля-тягача, швидкості центрів плям контакту коліс задньої осі автомобіля-тягача з опорною поверхнею знайдемо з виразів:

$$
\begin{aligned}
& v_{H_{13}}=v_{C_{1}}+\dot{\vartheta}_{1}\left(C_{1} B_{13}+B_{13} H_{13}\right)+\dot{\beta}_{3} \cdot B_{13} H_{13} \\
& v_{H_{13}^{\prime}}=v_{C_{1}}+\dot{\vartheta}_{1}\left(C_{1} B_{13}+B_{13} H_{13}^{\prime}\right)+\dot{\beta}_{3} \cdot B_{13} H_{13}^{\prime} .
\end{aligned}
$$

Із врахуванням рівнянь $(2,3,4,5,6)$ отримаємо:

для середнього моста автомобіля-тягача

$$
\begin{aligned}
& v_{H_{12}}=i_{1}\left[v_{1}-\omega_{1} n_{12} \cos \beta_{2}-\dot{\beta}_{2} n_{12} \cos \beta_{2}\right]+j_{0}\left[u_{1}-\omega_{1}\left(b_{12}-n_{12} \sin \beta_{2}\right)-\dot{\beta}_{2} n_{12} \sin \beta_{2}\right] ; \\
& v_{H_{12}^{\prime}}=i_{1}\left[v_{1}+\omega_{1} n_{12}^{\prime} \cos \beta_{2}+\dot{\beta}_{2} n_{12}^{\prime} \cos \beta_{2}\right]+j_{1}\left[u_{1}-\omega_{1}\left(b_{12}+n_{12}^{\prime} \sin \beta_{2}\right)-\dot{\beta}_{2} n_{12}^{\prime} \sin \beta_{2}\right] ;
\end{aligned}
$$

для заднього моста автомобіля-тягача

$$
\begin{aligned}
& v_{H_{13}}=i_{1}\left[v_{1}-\omega_{1} n_{13} \cos \beta_{3}-\dot{\beta}_{3} n_{13} \cos \beta_{3}\right]+j_{1}\left[u_{1}-\omega_{1}\left(b_{13}-n_{13} \sin \beta_{3}\right)-\dot{\beta}_{3} n_{13} \sin \beta_{3}\right] \\
& v_{H_{13}^{\prime}}=i_{1}\left[v_{1}+\omega_{1} n_{13}^{\prime} \cos \beta_{3}+\dot{\beta}_{3} n_{13}^{\prime} \cos \beta_{3}\right]+j_{1}\left[u_{1}-\omega_{1}\left(b_{13}+n_{13}^{\prime} \sin \beta_{3}\right)-\dot{\beta}_{3} n_{13}^{\prime} \sin \beta_{3}\right] ;
\end{aligned}
$$

Зважаючи на те, що:

$$
\begin{aligned}
& \operatorname{tg}\left(\beta_{2}+\delta_{2}\right)=\frac{\left(v_{H_{12}}\right)_{Y_{0}}}{\left(v_{H_{12}}\right)_{X_{0}}} ; \\
& \operatorname{tg}\left(\beta_{2}+\delta_{2}^{\prime}\right)=\frac{\left(v_{H_{12}^{\prime}}\right)_{Y_{0}}}{\left(v_{H_{12}^{\prime}}\right)_{X_{0}}} ; \\
& \operatorname{tg}\left(\beta_{3}+\delta_{3}\right)=\frac{\left(v_{H_{13}}\right)_{Y_{0}}}{\left(v_{H_{13}}\right)_{X_{0}}} ; \\
& \operatorname{tg}\left(\beta_{3}+\delta_{3}^{\prime}\right)=\frac{\left(v_{H_{13}^{\prime}}\right)_{Y_{0}}}{\left(v_{H_{13}^{\prime}}\right)_{X_{0}}} ;
\end{aligned}
$$

кути відведення коліс середньої та задньої осей автомобіля тягача знайдемо із рівнянь:

середньої

$$
\begin{aligned}
& \delta_{2}=-\beta_{2}-\operatorname{arctg}\left[\frac{u_{1}-\omega_{1}\left(b_{12}-n_{12} \sin \beta_{2}\right)-\dot{\beta}_{2} n_{12} \sin \beta_{2}}{v_{1}-\omega_{1} n_{12} \cos \beta_{2}-\dot{\beta}_{2} n_{12} \cos \beta_{2}}\right] \\
& \delta_{2}^{\prime}=-\beta_{2}-\operatorname{arctg}\left[\frac{u_{1}-\omega_{1}\left(b_{12}+n_{12}^{\prime} \sin \beta_{2}\right)-\dot{\beta}_{2} n_{12}^{\prime} \sin \beta_{2}}{v_{1}+\omega_{1} n_{12}^{\prime} \cos \beta_{2}+\dot{\beta}_{2} n_{12}^{\prime} \cos \beta_{2}}\right]
\end{aligned}
$$

задньої 


$$
\begin{aligned}
& \delta_{3}=-\beta_{3}-\operatorname{arctg}\left[\frac{u_{1}-\omega_{1}\left(b_{13}-n_{13} \sin \beta_{3}\right)-\dot{\beta}_{3} n_{13} \sin \beta_{3}}{v_{1}-\omega_{1} n_{13} \cos \beta_{3}-\dot{\beta}_{3} n_{13} \cos \beta_{3}}\right] ; \\
& \delta_{3}^{\prime}=-\beta_{3}-\operatorname{arctg}\left[\frac{u_{1}-\omega_{1}\left(b_{13}+n_{13}^{\prime} \sin \beta_{3}\right)-\dot{\beta}_{3} n_{13}^{\prime} \sin \beta_{3}}{v_{1}+\omega_{1} n_{13}^{\prime} \cos \beta_{3}+\dot{\beta}_{3} n_{13}^{\prime} \cos \beta_{3}}\right] .
\end{aligned}
$$

По аналогії визначимо кути відведення коліс осей підкатного візка та напівпричепа: для підкатного візка

$$
\begin{aligned}
& \delta_{4}=-\beta_{4}-\operatorname{arctg}\left[\frac{u_{2}-\omega_{2}\left(b_{21}-n_{21} \sin \beta_{4}\right)-\dot{\beta}_{4} n_{21} \sin \beta_{4}}{v_{2}-\omega_{2} n_{21} \cos \beta_{4}-\dot{\beta}_{4} n_{21} \cos \beta_{4}}\right] ; \\
& \delta_{4}^{\prime}=-\beta_{4}-\operatorname{arctg}\left[\frac{u_{2}-\omega_{2}\left(b_{21}+n_{21}^{\prime} \sin \beta_{4}\right)-\dot{\beta}_{4} n_{21}^{\prime} \sin \beta_{4}}{v_{2}+\omega_{2} n_{21}^{\prime} \cos \beta_{4}+\dot{\beta}_{4} n_{21}^{\prime} \cos \beta_{4}}\right] ; \\
& \delta_{5}=-\beta_{5}-\operatorname{arctg}\left[\frac{u_{2}-\omega_{2}\left(b_{22}-n_{22} \sin \beta_{5}\right)-\dot{\beta}_{5} n_{22} \sin \beta_{5}}{v_{2}-\omega_{2} n_{22} \cos \beta_{5}-\dot{\beta}_{5} n_{22} \cos \beta_{5}}\right] ; \\
& \delta_{5}^{\prime}=-\beta_{5}-\operatorname{arctg}\left[\frac{u_{2}-\omega_{2}\left(b_{22}+n_{22}^{\prime} \sin \beta_{5}\right)-\dot{\beta}_{5} n_{22}^{\prime} \sin \beta_{5}}{v_{2}+\omega_{2} n_{22}^{\prime} \cos \beta_{5}+\dot{\beta}_{5} n_{22}^{\prime} \cos \beta_{5}}\right] ;
\end{aligned}
$$

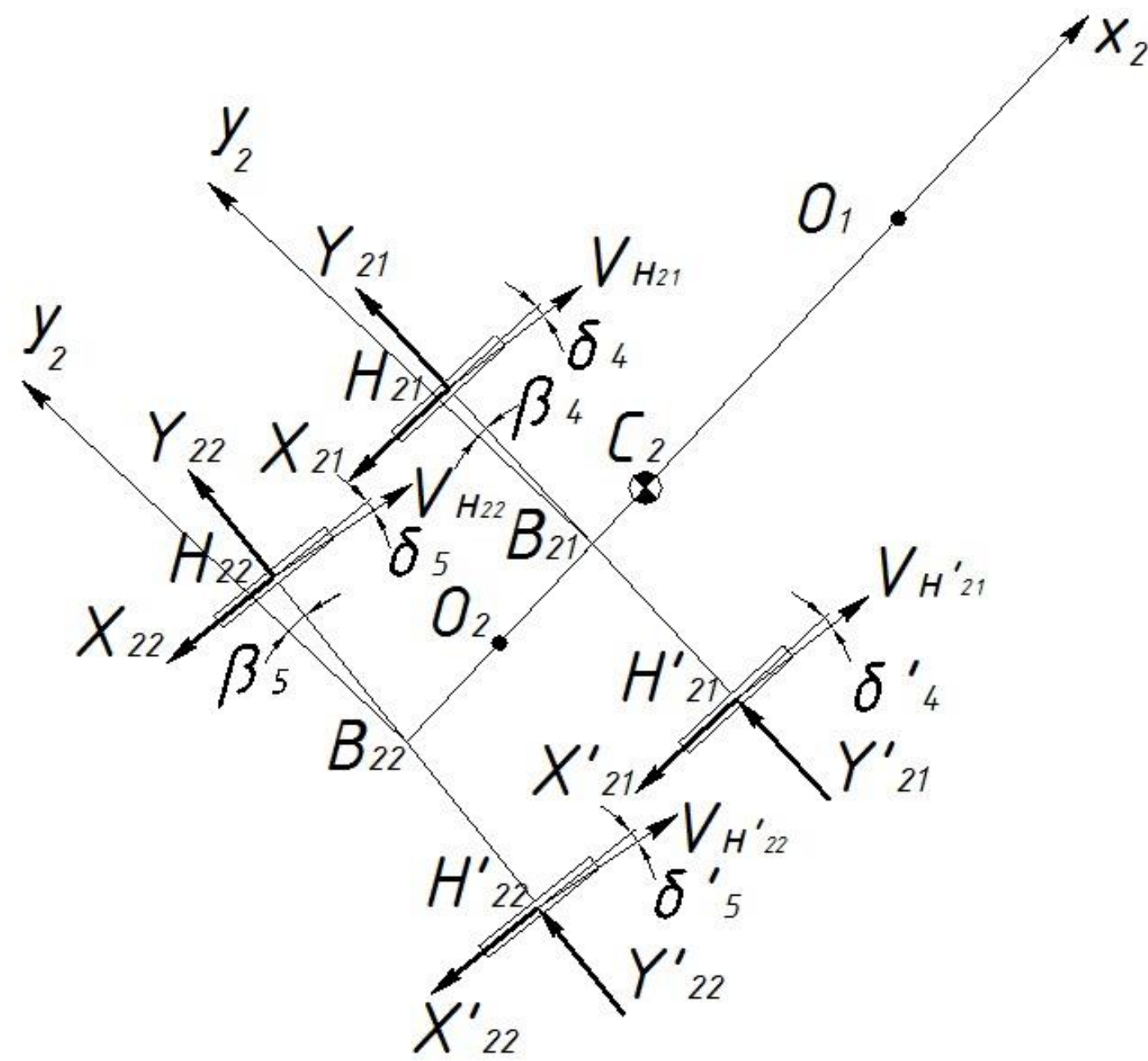

для напівпричепа

Рисунок 3 - До визначення кутів відведення коліс підкатного візка 


$$
\begin{aligned}
& \delta_{6}=-\beta_{6}-\operatorname{arctg}\left[\frac{u_{3}-\omega_{3}\left(b_{31}-n_{31} \sin \beta_{6}\right)-\dot{\beta}_{6} n_{31} \sin \beta_{6}}{v_{3}-\omega_{3} n_{31} \cos \beta_{6}-\dot{\beta}_{6} n_{31} \cos \beta_{6}}\right] ; \\
& \delta_{6}^{\prime}=-\beta_{6}-\operatorname{arctg}\left[\frac{u_{3}-\omega_{3}\left(b_{31}+n_{31}^{\prime} \sin \beta_{6}\right)-\dot{\beta}_{6} n_{31}^{\prime} \sin \beta_{6}}{v_{3}+\omega_{3} n_{31}^{\prime} \cos \beta_{6}+\dot{\beta}_{6} n_{31}^{\prime} \cos \beta_{6}}\right] ; \\
& \delta_{7}=-\beta_{7}-\operatorname{arctg}\left[\frac{u_{3}-\omega_{3}\left(b_{32}-n_{32} \sin \beta_{7}\right)-\dot{\beta}_{7} n_{32} \sin \beta_{7}}{v_{3}-\omega_{3} n_{32} \cos \beta_{7}-\dot{\beta}_{7} n_{32} \cos \beta_{7}}\right] ; \\
& \delta_{7}^{\prime}=-\beta_{7}-\operatorname{arctg}\left[\frac{u_{3}-\omega_{3}\left(b_{32}+n_{32}^{\prime} \sin \beta_{7}\right)-\dot{\beta}_{7} n_{32}^{\prime} \sin \beta_{7}}{v_{3}+\omega_{3} n_{32}^{\prime} \cos \beta_{7}+\dot{\beta}_{7} n_{32}^{\prime} \cos \beta_{7}}\right] ; \\
& \delta_{8}=-\beta_{8}-\operatorname{arctg}\left[\frac{u_{3}-\omega_{3}\left(b_{33}-n_{33} \sin \beta_{8}\right)-\dot{\beta}_{8} n_{33} \sin \beta_{8}}{v_{3}-\omega_{3} n_{33} \cos \beta_{8}-\dot{\beta}_{8} n_{33} \cos \beta_{8}}\right] ; \\
& \delta_{8}^{\prime}=-\beta_{8}-\operatorname{arctg}\left[\frac{u_{3}-\omega_{3}\left(b_{33}+n_{33}^{\prime} \sin \beta_{8}\right)-\dot{\beta}_{8} n_{33}^{\prime} \sin \beta_{8}}{v_{3}+\omega_{3} n_{33}^{\prime} \cos \beta_{8}+\dot{\beta}_{8} n_{33}^{\prime} \cos \beta_{8}}\right] ;
\end{aligned}
$$

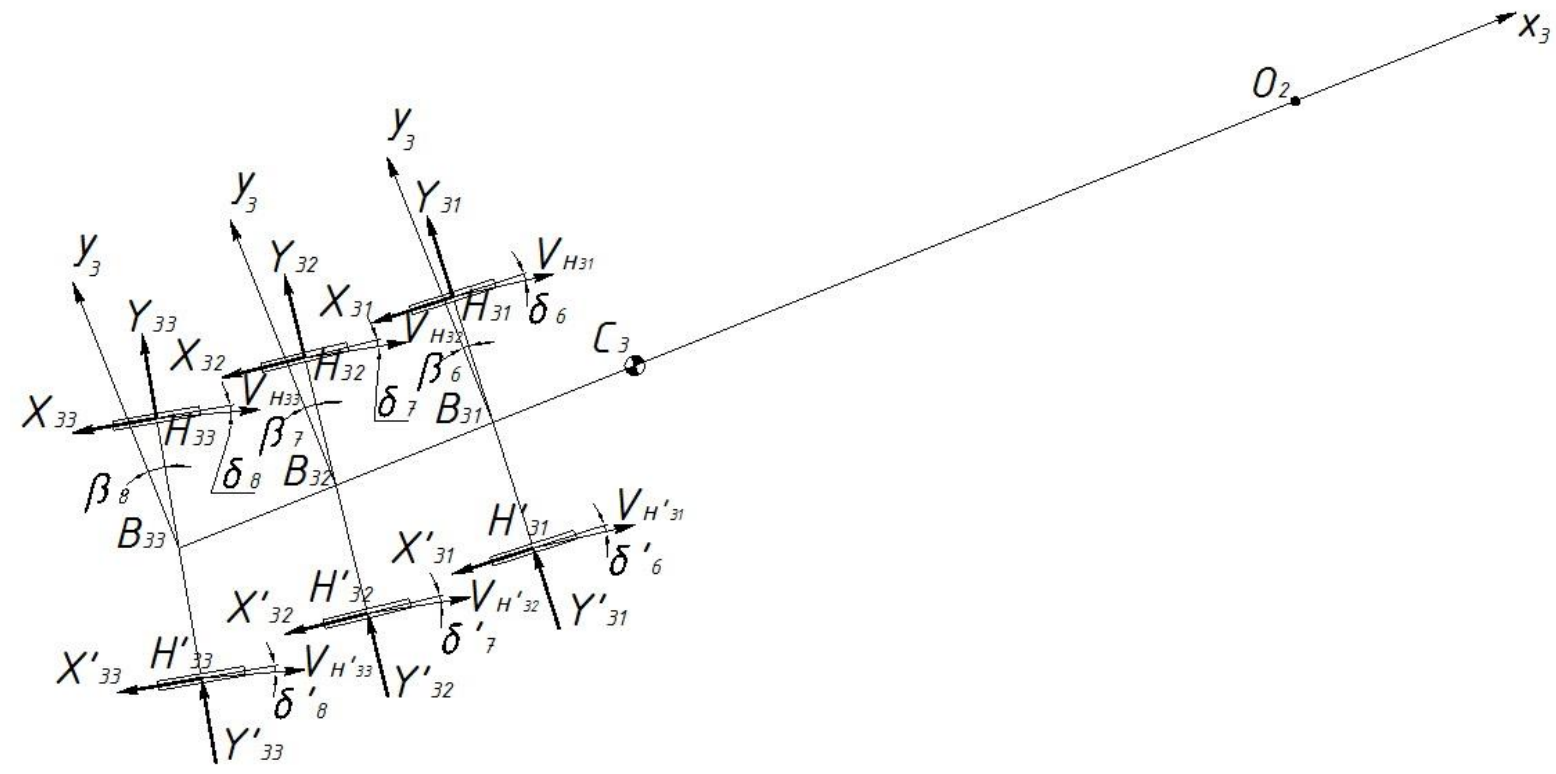

Рисунок 4 - До визначення кутів відведення коліс напівпричепа

Висновок. У роботі визначено основні кінематичні та геометричні співвідношення та розроблено рівняння для знаходження кутів відведення коліс осей ланок при русі модульного триланкового причіпного автопоїзда у складі «автомобіль-тягач - двовісний підкатний візок тривісний напівпричіп». Це дозволить у теоретичних дослідженнях визначати вплив компонувальної схеми та режимів руху на стійкість автопоїзда у гальмівному режимі, врахувавши при цьому кути встановлення осей ланок та кути відведення коліс.

1. Гандзюк М.О., Селезньов Е.Л., Гандзюк Д.М. Розробка плоскої математичної моделі руху модульного триланкового причіпного автопоїзда у складі «автомобіль-тягач - двовісний підкатний візок з неповоротними осями (dolly) тривісний напівпричіп // Наукові нотатки: Міжвузівський збірник, випуск 55, Луцьк: Редакційно видавничий відділ Луцького НТУ, 2016 - С.72-79.

2. Лобас Л.Г. Математическая модель связанных систем с качением // Прикладная механика. 1986, №6. -C80-87.

3. Лобас Л.Г. Неголономные модели колесных экипажей. - К.: Наукова думка, 1986. - 232 с.

4. Лобас Л. Г. Механика многозвенных систем с качением / Л.Г. Лобас. - К. : Наукова думка, 2000. - 270 с.

5. Поляков В.М., Тімков О.М., Приходченко Д.Ю., Файчук М.І. Математичне моделювання руху багатоланкових автопоїздів // Вісник Східноукраїнського національного університету імені Володимира Даля. Науковий журнал. -№11 (141). - 2009. - C.145-151. 
6. Сахно В.П., Вороніна І.Ф., Стельмащук В.В. Поляков В.М. Вплив конструктивних і експлуатаційних факторів на показники маневреності трьохланкових автопоїздів // Автошляховик України. Окремий випуск. - 2003. Жовтень. - С.98-101.

7. Сахно В.П., Вербицький В.Г., Вороніна І.Ф., Стельмащук В.В. До визначення показників маневреності і стійкості руху трьохланкових автопоїздів // Системні методи керування, технологія та організація виробництва. ремонту та експлуатації автомобілів. - К.:НТУ, 2003. - №17. - С.141-146.

8. Сахно В. П. Математичне моделювання триланкових автопоїздів в поздовжній, вертикальній і поперечній площинах / В.П. Сахно, В.М. Поляков, В.М. Глінчук // Вісник Донецької академії автомобільного транспорту. Науковий журнал, 2013. - Вип. 3. - С.73-84.

9. Сахно В.П. Порівняльна оцінка маневреності триланкових автопоїздів різних компонувальних схем / В.П. Сахно, В.М. Поляков, Р.М. Марчук, П.О. Гуменюк // Автомобільний транспорт. Науково-виробничий журнал, 2013. - №1 (231). C.2-6.

10. Сахно В. П. До визначення кутів відведення коліс транспортних засобів при дослідженні стійкості руху / В. П. Сахно, С. В. Гейко, О. А. Крестянполь // Автошляховик України. Окремий випуск. Вісник Центрального наукового центру Транспортної Академії України, 1999. - Випуск № 2. - С. 93-97.

11. Соцков Д. А. Повышение активной безопасности автотранспортних средств при торможении: дис. на соиск. учен. степ. д-ра техн. наук / Д. А. Соцков. - Владимир, 1988. - 410 с.

12. Автотранспортні засоби. Гальмівні властивості. Терміни та визначення : ДСТУ 2886:94. - [Чинний від 1996-0101]. - К. : Держстандарт України, 1996. - 28 с. - (Державний стандарт України).

13. Стійкість дорожньо-транспортних засобів. Терміни та визначення : ДСТУ 3736:98. - [Чинний від 1999-07-01]. Офіц. вид. - К. : Держстандарт України, 1999. - III, 11 с. - (Державний стандарт України). - Укр. та рос. мовами.

14. Засоби транспортні дорожні. Стійкість. Методи визначення основних параметрів випробуванням : ДСТУ $3310: 96$. - [чинний від 1997-01-01]. - Офіц. вид. - К. : Держстандарт України, 1996. - 10 с. - (Державний стандарт України).

15. ДСТУ UN/ECE R 13-09:2002. Сдині технічні приписи щодо офіційного схвалення типу транспортних засобів категорій М N та О стосовно гальмування: Правила ЄЕК ООН № 13. - [Чинні від 14.01.2008]. - Женева : Європейська Економічна Комісія Організації Об'єднаних націй, 2008. - 276 с.

\section{REFERENCES}

1. Gandzyuk, M.O., \& Seleznev, E.L., \& Gandzyuk, D.M. (2016). Rozrobka ploskoyi matematychnoyi modeli rukhu modul'noho trylankovoho prychipnoho avtopoyizda u skladi «avtomobil'-tyahach - dvovisnyy pidkatnyy vizok z nepovorotnymy osyamy (dolly) - tryvisnyy napivprychip» [Development of flat mathematical model of motion of the module three-unit towed lorry convoy in composition a «car-tractor is a biaxial pidkatniy light cart with irrevocable axes (dolly) is a triaxial semitrailer]. Naukovi notatky - The Scientific notes, 55, $72-79$ [in Ukrainian].

2. Lobas, L.G. (1986). Matematicheskaya model' svyazannyh sistem s kacheniem [Mathematical model of coupled systems with rolling]. Prikladnaya mekhanika - Applied mechanics, 6, 80-87 [in Ukrainian].

3. Lobas L.G. (1986). Negolonomnye modeli kolesnyh ehkipazhej [Nonholonomic models of wheeled carriages]. Naukova dumka - Scientific thought, 232 p. [in Ukrainian].

4. Lobas L.G. (2000). Mekhanika mnogozvennyh sistem s kacheniem [Mechanics of multilink systems with rolling]. Naukova dumka - Scientific thought, 270 p. [in Ukrainian].

5. Polyakov V., \& Timkov A., \& Pryhodchenko D., \& Faichuk N. (2009). Matematychne modeliuvannia rukhu bahatolankovykh avtopoizdiv [Mathematical modeling of motion of multilink trucks ]. Visnyk Skhidnoukrainskoho natsionalnoho universytetu imeni Volodymyra Dalia - Bulletin of East-Ukrainian national University named after Volodymyr Dahl, 11 (141),145151 [in Ukrainian].

6. Sakhno, V.P., \& Voronina, I.F., \& Stel'mashchuk, V.V., \& Polyakov, V.M. (2003). Vplyv konstruktyvnykh i ekspluatatsiynykh faktoriv na pokaznyky manevrenosti tr'okhlankovykh avtopoyizdiv [Influence of constructive and operational factors on indicators of maneuverability of three-axle road trains]. Avtoshlyakhovyk Ukrayiny - SUV of Ukraine, Installment, 98-101 [in Ukrainian].

7. Sakhno, V.P., \& Verbyts'kyy, V.H., \& Voronina, I.F., \& Stel'mashchuk, V.V. (2003). Do vyznachennya pokaznykiv manevrenosti i stiykosti rukhu tr'okhlankovykh avtopoyizdiv [To determination of indicators of maneuverability and stability of three-lane trains]. Systemni metody keruvannya, tekhnolohiya ta orhanizatsiya vyrobnytstva, remontu ta ekspluatatsiyi avtomobiliv System management methods, technology and organization of production, repair and operation of cars, 17, 141-146 [in Ukrainian].

8. Sakhno, V.P. (2013). Matematychne modelyuvannya trylankovykh avtopoyizdiv v pozdovzhniy, vertykal'niy i poperechniy ploshchynakh [Mathematical modeling of three-axle road trains in longitudinal, vertical and transverse planes]. Visnyk Donets'koyi akademiyi avtomobil'noho transport - Bulletin of the Donetsk Academy of Motor Transport, 3, 73-84 [in Ukrainian].

9. Sakhno, V.P. (2013). Porivnyal'na otsinka manevrenosti trylankovykh avtopoyizdiv riznykh komponuval'nykh skhem [Comparative estimation of maneuverability of trilanked automobile trains of different layout schemes]. Avtomobil'nyy transport Automobile transport, 1 (231), 2-6 [in Ukrainian].

10. Sakhno V. P. (1999). Do vyznachennia kutiv vidvedennia kolis transportnykh zasobiv pry doslidzhenni stiikosti rukhu [To the determination of the angles of removal of the wheels of vehicles in the study of stability of motion]. Avtoshliakhovyk Ukrainy - Roadster of Ukraine, 2, 93-97 [in Ukrainian].

11. Sotskov D.A. (1988). Povyshenie aktivnoj bezopasnosti avtotransportnih sredstv pri tormozhenii [Increase of active safety of motor vehicles during braking]. Doctor's thesis. Vladimir [in Russian].

12. Avtotransportni zasoby. Halmivni vlastyvosti. Terminy ta vyznachennia [Motor vehicles. Brake properties. Terms and definitions]. (1996). DSTU 2886:94 from $01^{\text {th }}$ January 1996. Kyiv: Derzhstandart Ukraine, [in Ukrainian].

13. Stiikist dorozhno-transportnykh zasobiv. Terminy ta vyznachennia [Sustainability of road vehicles. Terms and definitions]. (1999). DSTU 3736:98 from 01 ${ }^{\text {th }}$ July 1999. Kyiv: Derzhstandart Ukraine, [in Ukrainian].

14. Zasoby transportni dorozhni. Stiikist. Metody vyznachennia osnovnykh parametriv vyprobuvanniam [Means of transport road. Stability. Methods of determining the main parameters of the test]. (1996). DSTU 3310:96 from 01 ${ }^{\text {th }}$ January 1997. Kyiv: Derzhstandart Ukraine, [in Ukrainian]. 
15. Yedyni tekhnichni prypysy shchodo ofitsiinoho skhvalennia typu transportnykh zasobiv katehorii $\mathrm{M} \mathrm{N}$ ta $\mathrm{O}$ stosovno halmuvannia [Uniform technical prescriptions concerning the official approval of vehicles of categories $\mathrm{M} \mathrm{N}$ and $\mathrm{O}$ with respect to braking]. (2008). DSTU UN/ECE R 13-09:2002 from 14 ${ }^{\text {th }}$ January 2008. Geneva: United Nations Economic Commission for Europe.

N. Gandzyuk, D. Gandzyuk To the question of the investigation of motion of the modular three-unit trailer road train in the "car-towing-dolly-axle truck - three-axle semitrailer" in the braking mode.

An effective means of reducing the number of vehicles while maintaining volumes of freight is the use of trains. In our time, trains are used in many countries of the world. Due to the relative structural simplicity and shorter lengths at the same level of load capacity, and taking into account a number of other advantages, trailed trains have received a significant recognition and are most commonly used in the provision of freight transport.

Given the increasing intensity of traffic on modern highways, it is necessary to increase the safety of vehicles in order to avoid emergency situations, which results in worsening of human health and significant material losses in case of damage to vehicles and goods. This issue is particularly acute in the case of automobile trains, the process of movement and braking which is much more complicated than in individual cars. It is necessary that the braking system allows to regulate the speed of the carriage in a wide range, counterbalance the slides, and also makes it impossible to assemble the parts of the vehicle and its collision with other cars, that is, it provides the appropriate stability.

In view of this, improving the performance of trains in modern conditions of traffic is one of the priority tasks to ensure a high level of safety of their operation with the maximum efficiency of use.

The question arises regarding the prediction of exchange rate stability and the safety of the movement of a trailer with a different technical condition of its braking system and chassis. Taking into account the influence of these factors on the stability of the trains in the production process and in the conditions of operation, forecasting and analysis of its behavior is an important problem that needs a comprehensive solution. For its solution, it is necessary to carry out research of the processes occurring in the running and braking system under the influence of operational factors, to analyze the individual and joint influence of the change in the technical condition of the braking system and the geometry of the suspension on the braking dynamics of the trains.

These circumstances lead to the search for methods for assessing the stability of the trains in the braking mode.

In order to solve this problem, the main kinematic and geometric relations are defined in the paper, and the equation for finding the angles of the wheel drive of the axes of the links during the movement of the modular three-lane trailer car trains in the structure of the "car-tractor - two-axle podcasting trolley - three-axle semi-trailer" in the braking mode is developed.

This will allow in theoretical studies to determine the effect of the layout scheme and the modes of movement of the specified trailer to its stability in the braking mode, taking into account the angles of the axes.

Keywords: trailer; modular tree unit; layout scheme, trailer unit; trailer road train; semi-trailer; wheeled carriage; mathematical model; performance properties; stability; braking mode.

АВТОРИ:

ГАНДЗЮК Микола Олександрович, кандидат технічних наук, доцент кафедри автомобілів і транспортних технологій Луцького національного технічного університету, е-таil: Gandzyuk64.MG@gmail.com.

ГАНДЗЮК Дмитро Миколайович, магістр із спеціальності «Автомобілі і автомобільне господарство», аспірант Луцького національного технічного університету, е-таil: Gandzyukd@gmail.com.

АВТОРЫ:

ГАНДЗЮК Николай Александрович, кандидат технических наук, доцент кафедры автомобилей и транспортных технологий Луцкого национального технического университета, e-mail: Gandzyuk64.MG@gmail.com.

ГАНДЗЮК Дмитрий Николаевич, магистр по специальности «Автомобили и автомобильное хозяйство», аспирант Луцкого национального технического университета, е-таil: Gandzyukd@gmail.com.

\section{AUTHORS:}

Mykola HANDZIUK, Ph.D in Engeneering, associate professor of automobiles and transport technologies department, Lutsk National Technical University, e-mail: Gandzyuk64.MG@gmail.com.

Dmitriy GANDZYUK, Magistr of Transport, Postgraduate Student of Lutsk National Technical University, e-mail: Gandzyukd@gmail.com. 